\title{
The Influence of Job Embeddednees on Turnover Intentions Among Advertising Managers
}

\author{
Jim DeConinck \\ Western Carolina University. United States \\ Julie Johnson-Busbin \\ Western Carolina University. United States \\ Mary Beth DeConinck \\ Western Carolina University. United States \\ James Busbin \\ Western Carolina University. United States
}

\begin{abstract}
In recent years, job embeddedness has been the focus of extensive research because of its relationship to employees' turnover behavior. This research developed and tested a model, with a sample of advertising managers, examining the role of perceived supervisor support (PSS) as a mediator between organizational justice and job embeddedness. Distributive justice, interactional justice, and procedural justice were predictors of PSS. The relationship between organizational justice and job embeddedness was indirect through PSS. The results have important implications for controlling turnover.
\end{abstract}

Keywords: Job embeddedness, perceived support, organizational justice, turnover intentions

\section{INTRODUCTION}

Turnover has been an important area of study for many years because of its detrimental costs to organizations $[24,25,27]$. A major reason that employees leave their jobs is the perception they have not been treated fairly by their employers $[3,17]$. If employers better understood causes of turnover, efforts could be made to reduce or eliminate issues that lead to turnover. While models of turnover have been developed over the last 40 years, much of the variance in turnover has not been predicted [27]. For this reason, job embeddedness was proposed by Mitchell et al. [40] to account for unique variance in turnover not explained in previous models based on job alternatives and job attitudes [26, 41]. Job embeddedness theory involves examining forces that bind employees to their jobs [10]. In their meta-analysis of job embeddedness, Jiang et al. [30] reported that after controlling for job alternatives, job satisfaction, and organizational commitment, job embeddedness was related negatively to both turnover intentions and actual turnover. In addition, beyond the influence of job alternatives and job attitudes, unique variation in turnover is explained by job embeddedness [15].

While the initial focus of job embeddedness was with its relationship to turnover, in the past few years, it has become an important area of research because of its relationship to important job attitudes. However, research investigating the relationship between job embeddedness and employees' job attitudes is sparse. Recently, research has analyzed two variables, perceived organizational support (POS) [4, 44] and organizational justice [10], and how they influence job embeddedness. POS and organizational justice have been the focus of much 
research because of their relationship to important job attitudes and behaviors (see metaanalyses by $[9,12,13,32,47]$.

This study has two purposes. First, only two studies have investigated the relationship between POS and job embeddedness $(4,44)$. However, no study has examined the influence of perceived supervisor support (PSS), even though PSS and POS are highly correlated (46). Intuitively, support from the supervisor, perhaps as much or more than support from the organization, should be an important determinant of an employee's decision to stay with the organization. This study will examine the link between PSS, rather than POS, and job embeddedness.

The second purpose of this study is to answer the question, what is the relationship between organizational justice and job embeddedness? The two studies that examined the relationship between organizational justice and job embeddedness have not included all three facets of organizational justice (distributive, procedural, and interactional). Are all three components of organizational justice antecedents of job embeddedness? Is organizational justice related directly to job embeddedness or is the relationship mediated by PSS?

This study will extend prior research by examining the relationship among organizational justice, PSS, job embeddedness, and turnover intentions. This study will develop and test hypothesized relationships with a sample of advertising employees. Support for the relationships is presented in the literature review.

\section{Social Exchange Theory}

\section{LITERATURE REVIEW}

Social exchange theory (SET) derived from the work of Gouldner [21] and Blau [6] and has been used as a basis for both organizational justice and perceived support (14). Blau [6] describes social exchange as "the voluntary action of individuals that are motivated by the returns they are expected to bring and typically do in fact bring from others" (p. 91). Blau [6] made an important contribution to SET by differentiating between economic and social exchanges. Economic exchanges such as a pay raise or promotion involve specified obligations while social exchanges involve unspecified obligations that cannot be bargained and create future and enduring obligations between the parties.

Employees who perceive that the organization cares about them and treats them fairly will feel an obligation to reciprocate through positive job attitudes and behavior [14]. Fairness (organizational justice) can be viewed as a source of exchange or reciprocity. Employees who perceive they have been treated fairly and that the organization supports them will feel an obligation to reciprocate through their attitudes and actions [52].

\section{Organizational Justice}

Organizational justice consists of four dimensions: distributive justice, procedural justice, and interactional justice, which is comprised of interpersonal justice and informational justice. Although the presence of four distinct measures of organizational justice has been validated [11], each form of justice involves employees' assessment of the benefits received in exchange for their contributions to the organization [13]. Organizational justice has been found to be an important determinant of employees' behavior $[9,11]$.

Distributive justice, derived in social psychology from the work of Homans [28] and Adams [1], involves the perception of fairness in outcome decisions. Homans [28] argued that interaction 
between employees and employers establish expectations of exchange (i.e., distributive justice). Employees expect to receive rewards based on their investments and of effort they put forth. The determination as to what is fair is psychologically based and subjective. Research indicates that distributive justice is linked to employees' attitudes and behaviors [9, $12,13]$.

Procedural justice focuses on the methods, mechanisms and processes by which decisions are made [12] and effects employees' view of the value of their association with the company [38]. Thibaut and Walker's [51] work concerning dispute resolution was the beginning of procedural justice. Their research focused on examining whether a favorable outcome could be mitigated by the perceived fairness of the process that was used to reach the decision. Based on evaluating both the process stage and decision stage of the proceedings, they concluded that the process by which the outcome was determined was, in some cases, more important than the actual outcome.

Although employees may believe that a reward is unfair, they will feel obligated to reciprocate to the organization through their attitudes and behavior, if the process by which the reward was determined is perceived to be fair [50]. An important aspect of procedural justice is that, when people have a voice in the process, they perceive it as fairer [20]. Research indicates that an employee's supervisor plays a key role in the perception of procedural justice [20]. Research found that distributive justice predicts an outcome directly relevant to the employee such as pay satisfaction, while procedural justice is related to outcomes relevant to the organization such as organizational commitment and trust [17, 20].

Interactional justice involves the interpersonal treatment employees obtain from management and is less formalized than procedural justice [5]. It involves the level of respect, sensitivity, and honesty shown by management when interacting with subordinates. Interactional justice consists of two components: informational justice - the adequacy, timeliness, and truthfulness of communications and interpersonal justice - politeness and respectfulness displayed during the communications between the parties [12]. An important difference between procedural justice and interactional justice is that perceptions of interactional justice are directed toward the supervisor while procedural justice involves subordinates' perceptions of fairness directed toward the organization $[38,43]$. Research found employees who receive an unfavorable outcome decision are more likely to be accept the decision when management provides timely information (informational justice) and treats them employees with respect (interpersonal justice) [22].

\section{Perceived Support}

Based on social exchange theory, POS involves the degree to which the organization cares about employees' well-being and values their contribution [18]. Employees exchange their effort and dedication to the company to obtain financial benefits and to meet socio-emotional needs. When POS is high, employees will feel more committed to the organization [46]. Trust will develop between the employee and the employer, which leads to long-term obligations for both parties. POS is correlated significantly to a variety of job attitudes including fairness, organizational commitment, psychological contract breach, and trust [32, 46].

PSS, the extent to which the supervisor values the employee's contributions, is highly correlated with POS [46]. While fewer studies have included PSS, it has been shown to an important determinant of employees' attitudes and behavior [17, 36, 49]. 


\section{Perceived Support and Organizational Justice}

Research has examined the influence of organizational justice on employee's level of POS. This research found that organizational justice is correlated significantly to POS $[2,46]$. Much less research has been conducted examining how organizational justice is related to PSS. Stinglhamber et al. [49] reported that PSS had a much higher correlation with interactional justice $(r-.78)$ than with procedural justice $(r-.33)$. DeConinck [16] reported that both distributive justice and interactional justice were related significantly to PSS while procedural justice was a significant predictor of POS. However, a recent study reported only a moderate correlation $(r=.28)$ between PSS and distributive justice [47]. Byrne et al. [7] reported that, of the three dimensions of organizational justice, only interactional justice was a predictor of PSS. Last, Colquitt et al. [13] conducted an updated meta-analysis regarding organizational justice. The authors reported that all dimensions of organizational justice were correlated highly with POS. These authors did not investigate the link between organizational justice and PSS.

Research indicates that organizational justice is an antecedent to POS. However, hypothesizing the relationship between PSS and organizational justice is difficult given the few studies that have examined the relationship between the two variables. Intuitively, perceived support from the supervisor should lead to employees' perception that they have been treated fairly by their supervisor.

H1: Organizational justice is related positively to PSS.

\section{Perceived Support and Turnover Intentions}

Employees who perceive that their supervisor supports their efforts should have a lower intention to leave their company. Research has shown that PSS is an antecedent to turnover intentions (e.g.,17, 36, 39).

H2: PSS is related negatively to turnover intentions.

\section{Job embeddedness}

Traditional models of turnover [41, 42] are based on March and Simon's [37] work that proposed that turnover was a function of the desirability of leaving a job and the ease of movement. These models suggest that turnover is a function of job satisfaction, intention to search, perceived alternatives, quit intentions (15). Steers and Mowday [48], expanded these models by including both job satisfaction and organizational commitment.

Lee and Mitchell [35], in their unfolding model of voluntary turnover, suggested that, in addition to job dissatisfaction, shocks and disturbing events that cause employees to consider quitting, were also important determinants of turnover. In an effort to explain why people stay, Mitchell et al. [40] developed the concept of job embeddedness. They proposed that a person's desire to stay is comprised of fit (compatibility) to the community or job, formal or informal links to other individuals, and sacrifices that derive from leaving. Both the organization and community impact fits, links, and sacrifices. Employees who have more links will feel more embedded to their job and the organization. The aggregate for the three dimensions rather than the individual dimensions determine job embeddedness [40]. Job embeddedness has become an important focus of turnover research [15].

Job embeddedness is distinct from organizational commitment and job satisfaction. Both organizational commitment and job satisfaction focus on job-related issues while job embeddedness focuses on both job-related issues and non-job-related issues. Additionally, in contrast to organizational commitment and job satisfaction, which examines specific reasons for leaving, job embeddedness is concerned with general reasons to remain attached to the 
organization. Research indicates that job embeddedness is highly correlated to turnover intentions $[15,30,40)]$

H3: Job embeddedness is related negatively to turnover intentions.

Research examining the relationship between job embeddedness and perceived support is sparse. No study could be found that included PSS and job embeddedness. A few studies have shown that POS is an antecedent to job embeddedness. For example, Allen and Shanock [4] reported a high correlation between the two variables $(r=.58)$, although the authors did not test a direct relationship. Nguyen et al. [44] reported that POS was a direct predictor of job embeddedness. However, the study involved employees from a state-owned company in Vietnam and may not be applicable to employees in the United States. Intuitively, employees who work for a supportive supervisor who cares about their well-being and provides help when needed should feel connected and attached to the organization and would find leaving difficult.

H4: PSS is related positively to job embeddedness

The relationship between organizational justice and job embeddedness is unclear. Is there a direct relationship between the two variables? Or is the relationship mediated by PSS? Collins and Mossholder [10] reported only a moderate correlation between job embeddedness and each facet of organizational justice. The results of the Collins and Mossholder [10] study indicate that PSS mediates the relationship between organizational justice and job embeddedness. Given the lack of research testing a direct link between organizational justice and job embeddedness, a second model will be tested examining if the relationship is direct or indirect through PSS.

\section{Sample}

\section{METHODOLOGY}

Data were obtained, using a direct mailing list, from a national sample of 1,500 advertising managers working in the United States. A letter was sent describing the purpose of the study along with the questionnaire. The advertising managers were asked to complete the questionnaire using a link provided to them. Thirty-eight surveys were returned as undeliverable. A total of 212 people completed the survey online. Two weeks later a second email message was sent asking for people to complete the survey if they had not done so. Forty-one additional people completed the survey. All but two surveys completed all the information. The final sample size was 252 .

The demographic profile of the respondents was as follows: their average age was 35.2 years, slightly more than half were male (136-54.2\%); they had an average of 7.2 years working for their company; the number of married people was 147 (58.2\%) while 121 respondents had children (49.2\%). Most of the respondents worked in middle and upper management positions $(218,86.9 \%)$.

\section{Measures}

Perceived Supervisor Support was measured using four items from the survey of perceived organizational support (SPOS) developed by Eisenberger et al. [18] $(\alpha=0.80)$. The word "supervisor" was substituted for "organization" in the SPOS. Job embeddedness was measured using Crosley's et al. [15] scale $(\alpha=0.88)$. Procedural Justice $(\alpha=0.90)$ and Interactional Justice $(\alpha=0.88)$ were measured using scales developed by Colquitt [12]. Following the procedure used by Collins and Mossholder [10], three items each from the interpersonal and informational justice dimensions were used to measure interactional justice. Distributive Justice was measured using the five-item scale developed by Price and Mueller [45] $(\alpha=0.94)$. 
Turnover intentions were measured using three items developed by Konovsky and Cropanzano $[31](\alpha=0.93)$.

\section{RESULTS}

The results were analyzed using LISREL 9.2. The means, standard deviations and correlation among the variables appear in Table 1.

\section{$\underline{\text { Table } 1 \text { - Correlations, Means, and Standard Deviations }}$}

\section{PSS}

$\mathrm{JE} \quad .54$

TI $\quad-.34-.39$

DJ $\quad .41 \quad .22 \quad-.14$

PJ $\quad .46 \quad .24 \quad-.15 \quad .34$

I] $\quad .50 \quad .26 \quad-.17 \quad .39 \quad .57$

$\begin{array}{lllllll}\text { Means } & 14.9 & 25.5 & 6.5 & 17.6 & 23.2 & 20.7\end{array}$

$\begin{array}{llllll}\text { Std. Dev. } \quad 2.9 & 6.5 & 3.2 & 3.8 & 5.2 & 5.0\end{array}$

PSS = perceived supervisor support, $\mathrm{JE}=$ job

embeddedness, $\mathrm{TI}=$ turnover intentions,

$\mathrm{DJ}=$ distributive justice, $\mathrm{PJ}=$ procedural

justice, $\mathrm{IJ}=$ interactional justice

The results of the confirmatory factor analysis (CFA) indicated a good fit $(\chi 2=817.8, d f=419$, $p=.00, \mathrm{GFI}=.86, \mathrm{AGFI}=.83, \mathrm{CFI}=.94$, RMSEA $=.06)$. Given the results of the CFA, the hypothesized model was assessed. The results for the hypothesized model indicated a good fit $(\chi 2=846.53, d f=425, p=.00, \mathrm{GFI}=.86, \mathrm{AGFI}=.83, \mathrm{CFI}=.94, \mathrm{RMSEA}=.061)$.

Support was found for each of the hypotheses, H1: Organizational justice is related positively to PSS: distributive justice $(\beta=.34, t=5.76)$; procedural justice $(\beta=.21, t=2.77)$; interactional justice $(\beta=.28, t=3.51)$; H2: PSS is related negatively to turnover intentions $(\beta=-.18, t=$ 2.31); H3: job embeddedness is related negatively to turnover intentions $(\beta=-.29, t=3.88)$; $\mathrm{H} 4$ : PSS is related positively to job embeddedness $(\beta=.54, t=7.62)$.

A second model was tested to ascertain if the three measures of organizational justice were related directly to job embeddedness. The fit of the second model did not indicate a statistically significant improvement over the hypothesized model $(\Delta \chi 2=4.72, d f=3, N S)$. Thus, the relationship between organizational justice and job embeddedness is indirect through PSS.

\section{CONCLUSIONS AND IMPLICATIONS}

The purpose of this research was to test a model including organizational justice, PSS, job embeddedness, and turnover intentions. A model was tested with one group of employees and then tested again with a second, and different, group of employees. This study expands prior research by including three facets of organizational justice (distributive, procedural, and interactional) in a model including embeddedness. In addition, this study includes PSS as a mediator between organizational justice and job embeddedness. The findings have important implications in understanding how organizational justice influences job embeddedness. The significance of the research is discussed below. 


\section{Theoretical Implications}

First, no study has investigated the relationship between PSS and job embeddedness. Perceived support has been an important variable influencing employees' job attitudes and behavior $(9,46)$. The lack of research examining the link between PSS and job embeddedness is surprising since both variables have been included in many studies. PSS was a highly significant predictor of job embeddedness. Advertising managers and marketing managers reported a higher desire to stay with their employer when their immediate supervisor provided them with support.

Second, the results indicated that all forms of justice were related significantly to PSS in the sample of advertising managers. While sparse research exists investigating the relationship between organizational justice and PSS, the results of this research have been mixed. This study's results corroborate the findings reported by DeConinck [16], Stinglhamber et al. [49], and Byrne et al. [7] showing that interactional justice predicts employees' perception of support they receive from their supervisor. The results also support, with respect to advertising managers, a significant relationship between distributive justice and PSS as reported by DeConinck [16] and Sousa-Lima et al. [47].

Another important theoretical implication of this study's results is the relationship between organizational justice and job embeddedness. No study has examined the relationship between all three facets of organizational justice and job embeddedness. One purpose of this study was to determine if organizational justice is a direct predictor of job embeddedness or if the relationship is mediated by PSS. The results from both studies indicate that organizational justice is an indirect predictor of job embeddedness through PSS.

\subsection{Managerial Implications}

Perceived supervisor support plays an important role in how embedded employees feel as well as how likely they are to leave the organization. Companies cannot overlook the importance of the supervisor and their relationship with employees. While employees may feel loyalty to an organization, a supervisor that is not perceived to be "fair" can lead to employee turnover. Organizations should to provide training for supervisors regarding actions they can take to appear supportive and communicative. For example, supervisors need to be aware of the way in which they interact with employees and be cognizant of the accuracy and timeliness of communication with subordinates. Supervisors may tend to rely on corporate communications to convey information rather than following up with employees and adding their own personal touches to the corporate communication. Supervisors need to be diligent in providing clear, and accurate communications in order to help employees feel supported. Also, supervisors need to be aware that the processes by which decisions are made should be clear and transparent so that employees feel more positive about the decisions. While it is less clear whether supervisors can control the way in which employees perceive their own input to output ratio, it appears that making sure employees feel valued is beneficial. Supervisors should be trained to build community amongst their employees so that multiple links are established, thus making the decision to leave the organization more difficult. Organizations may want to consider having regular, annual or semi-annual "check-ups" with employees via anonymous surveys which allow employees to voice their opinions regarding how well the supervisor is performing in organizational justice or fairness arenas. Providing supervisors with employee feedback, training to close the gaps on shortcomings, and developing a culture of understanding of the importance of these elements could lead not only to better supervisors, but happier employees and greater retention. 


\section{Limitations of Future Research Opportunities}

The results of this study offer several opportunities for future research. This study was the first one to develop and test a model containing three facets of organizational justice, PSS, job embeddedness, and turnover intentions. Distributive justice was a predictor of PSS only in Study 1 . In both studies organizational justice was related to job embeddedness only indirectly through PSS. Thus, additional research needs to test the model.

This study has several limitations. First, the study was cross-sectional. Future research should test the model within a single organization. Second, this study looked at turnover intentions, but not actual turnover. Third, this study was limited in scope. Future research should include additional variables including performance, job fit, and ethical leadership. Does an ethical leader influence employees' job embeddedness? Fourth, this model could be tested within a sales force context. Reducing sales force turnover has been an important area of research for many areas given the direct and indirect costs of replacing salespeople.

In conclusion, this study has shown the important role that organizational justice and PSS play in marketing employees' job embeddedness and indirectly their turnover intentions. These results have important implications in controlling turnover among marketing employees.

\section{References}

Adams, J. S. (1965). Inequity in social exchanges. In L. Berlowitz (Ed.), Advances in experimental social psychology, vol. 2: 267-299. New York: NY: Academic Press.

Ambrose, M. L. and Schminke, H. (2003). Organization structure as a moderator of the relationship between procedural justice, interactional justice, perceived organizational support, and supervisory trust. Journal of Applied Psychology, 88, 295-305.

Aquino, K., Griffeth, R. W., Allen, D. W. and Hom, P. W. (1997). Integrating justice constructs into the turnover process: A test of a referent cognitions model. Academy of Management Journal, 40, 1208.127.

Allen, D. G. and Shanock, L. R. (2013). Perceived organizational support and embeddedness as key mechanisms connecting socialization tactics to commitment and turnover among new employees. Journal of Organizational Behavior 34, 351-369.

Bies, R. J. and Moag, J. S. (1986). Interactional justice: Communication criteria of fairness. In R. J. Lewicki, B. H. Sheppard \& M. H. Bazerman (Eds.), Research on negotiations in organizations, vol. 1: 43-55. Greenwich, CT: JAI Press.

Blau, P. (1964), Exchange and Power in Social Life, New York: Wiley.

Byrne, Z. S., Pitts, V. E., Wilson, C. M., and Zachery, J. (2012. Trusting the fair supervisor: the role of supervisory support in performance appraisals. Human Resource Management Journal, 22, 129-148.

Cohen-Charash, Y. \& Spector, P. E. (2001). The role of justice in organizations: A meta-analysis. Organizational Behavior and Human Decision Processes, 86, 278-321.

Collins, B. J. and Mossholder, K. W. (2017). Fairness means more to some than others: Interactional fairness, job embeddedness, and discretionary work behaviors. Journal of Management, 43, 293-318.

Colquitt, J. A. (2001). Justice at the millennium: A meta-analytic review of 25 years of organizational justice research. Journal of Applied Psychology, 86, 425-446.

Colquitt, J. A., Greenberg, J. and Zapata-Phelan (2005). What is organizational justice? A historical review. In J. Greenberg \& M. Ambrose (Eds.), Handbook of Organizational Justice in Work Organizations: 113-152. Mahwah, NJ: Erlbaum.

Colquitt, J. A., Scott, B. A., Rodell, J. B., Long, D. M., Zapata, C. P., Conlon, D. E., and Wesson, M. J. (2013). Justice at the millennium, a decade later: A meta-analytic test of social exchange and affect-based perspectives. Journal of Applied Psychology 98, 199-236.

Cropanzano, R. and Mitchell M. (2005). Social exchange theory: An interdisciplinary review. Journal of Management, 31, 874-900. 
Crosley, C., Bennett, R., S. M., and Burnfield, J. (2007). Development of a global measure of job embeddedness and integration into a traditional model of voluntary turnover. Journal of Applied Psychology 92, 1031-1042.

DeConinck, J. B. (2010). The effect of organizational justice, perceived organizational support, and perceived supervisor support on marketing employees' level of trust. Journal of Business Research, 63, 1350-1355.

DeConinck, J. B. and Johnson, J. T. (2009). The effects of perceived supervisor support, perceived organizational support, and organizational justice on turnover among salespeople. Journal of Personal Selling \& Sales Management, 29, 333-351.

Eisenberger, R., Huntington, R., Hutchinson, S. and Sowa, D. (1986). Perceived organization support. Journal of Applied Psychology 71, 510-517.

Folger, R. and Cropanzano, R. (1988). Organizational justice and human resource management. Thousand Oaks, CA: Sage.

Folger, R. and Konovsky, M. A. (1989). Effects of procedural and distributive justice of reactions to pay raise decisions. Academy of Management Journal, 32, 115-130.

Gouldner, A. W. (1960). The norm of reciprocity: A preliminary statement. American Sociological Review, 25, 161178.

Greenberg, J. (1993). The social side of fairness: Interpersonal and informational classes of organizational justice, in Justice in the Workplace: Approaching Fairness in Human Resource Management, R. Cropanzano, (Ed). Hillsdale, NJ: Lawrence Erlbaum, 79-103.

Hair, J. F., Jr., Black, W. C., Babin, B. J., and Anderson, R. E. (2009). Multivariate Data Analysis, $7^{\text {th }}$ ed., Prentice Hall, Upper Saddle, NJ.

Hancock, J. L., Allen, D. G., and Soelberg, C. (2017). Collective turnover: An expanded meta-analytic exploration and comparison. Human Resource Management Review, 27, 61-86.

Heavey, A. L., Holwerda, J. A., and Hausknecht, J. P. (2013). Causes and consequences of collective turnover: A meta-analytic review. Journal of Applied Psychology, 98, 412-463.

Hom, P. W., and Griffeth, R. W. (1995). Employee turnover. Cincinnati, OH: South-Western College Publishing.

Hom, P. W., Lee, T. W., Shaw, J. D., and Hausknecht, J. P. (2017). One hundred years of employee turnover theory and research. Journal of Applied Psychology, 102, 530-546.

Homans, G. C. (1961). Social behavior: Its elementary forms. London, United Kingdom: Routledge\& Kegan Paul.

Hom, P. W. and Griffeth, R. W. (1995). Structural equations modeling test of a turnover theory: Cross-sectional and longitudinal analyses. The Journal of Applied Psychology 76, 351-366.

Jiang, K., Liu, D., McKay, P. F., Lee, T. W., and Mitchell, T. R. (2012). When and how is job embeddedness predictive of turnover? A meta-analytic investigation. Journal of Applied Psychology, 97, 1077-1096.

Konovksy, M. A. and Cropanzano, R. (1991). Perceived fairness of employee drug testing as a predictor of employee attitudes and job performance. Journal of Applied Psychology, 76, 698-707.

Kurtessis, J. N., Eisenberger, R., Ford, M. T., Buffardi, L. C., Stewart, K. A., and Adis, C. A. (2017. Perceived organizational support: A meta-analytic evaluation of organizational support theory. Journal of Management, 43, 1854-1884.

Lee, T. W., Hom, P. W., Eberly, M. B. Li, Junchao, and Mitchell, T. R. (2017). On the next decade in voluntary employee turnover. Academy of Management Perspectives, 31, 201-221.

Lee, T. W., Mitchell, T. R., Sablynski, C. J., Burton, J. P., and Holtom, B. C. (2004). The effects of job embeddedness on organizational citizenship, job performance, volitional absences, and voluntary turnover. Academy of Management Journal, 48, 711-722.

Lee, T. W. and Mitchell, T. R. (1994). An alternative approach: The unfolding model of voluntary turnover. Academy of Management Review 31, 52-89.

Maertz Jr., C. P., Griffeth, R. W., Campbell, N. S, and Allen, David, G. (2007). Journal of Organizational Behavior, 28, 1059-1075.

March, J. \& Simon, H. A. (1958). Organizations. New York: Wiley Press.

Masterson, S. S., Lewis, K., Goldman, B. M., and Taylor, S. M. 2000. Integrating justice and social exchange: The differing effects of fair procedures and treatment on work relationships. Academy of Management Journal, 43, 738-749. 
McCarthy, A., Cleveland, J. N., Hunter, S., Darcy, C., and Grady, C. (2013). Employee work-life balance outcomes in Ireland: A multilevel investigation of supervisory support and perceived organizational support. International Journal of Human Resource Management, 24, 1257-1276.

Mitchell, T. R., Holton, B. C., Lee, T. W., Sablynski, C. J. and Erez, M. (2001). Why people stay: Using job embeddedness to predict voluntary turnover. Academy of Management Journal 44, 102-1121.

Mobley, W. H. (1977). Intermediate linkages in the relationship between job satisfaction and employee turnover. The Journal of Applied Psychology 62, 237-240.

Mobley, W. H., Horner, S. O., and Hollingsworth, A. T. (1978). An evaluation of precursors of hospital employee turnover. Journal of Applied Psychology, 63, 408-414.

Moorman, R. H. (1991). Relationship between organizational justice and organizational citizenship behaviors: Do fairness perceptions influence employee citizenship? Journal of Applied Psychology, 76, 846-855.

Nguyen, V. Q., Taylor, G. S., and Bergiel, E. (2017). Organizational antecedents of job embeddedness. Management Research Review, 40, 1216-1235.

Price, J. L., and Mueller, C. W. (1986), Absenteeism and Turnover Among Hospital Employees, Greenwich, CT: JAI Press.

Rhoades, L. and Eisenberger, R. (2002). Perceived organizational support: A review of the literature. Journal of Applied Psychology 87, 698-714.

Sousa-Lima, M., Michel, J. W., and Caetano, A. (2013). Clarifying the importance of trust in organizations as a component of effective work relationships. Journal of Applied Social Psychology, 43, 418-427.

Steers, R. M. and Mowday, R. T. (1981). Employee turnover and post-decision accommodation processes. In L. L. Cummings \& B. M. Staw (Eds.), Research in organizational behavior (Vol. 3), Greenwich, CT: JAI Press, 235-282.

Stinglhamber, F., De Cremer, D., and Mercken, L. (2006). Perceived support as a mediator of the relationship between justice and trust. Group \& Organization Management, 31, 442-478.

Sweeney, P. D. and McFarlin D. B. (1993). Workers' evaluations of the 'ends' and the 'means': An examination of four models of distributive justice. Organizational Behavior \& Human Decision Processes, 93, 55, 23-41.

Thibaut, J. W. and Walker L. (1975). Procedural justice: A psychological analysis. Hillsdale, NJ: Erlbaum.

Wayne, S. J., Harris, K. J., and Sablynski, C. J. (2002). The role of fair treatment and rewards in perceptions of organizational support and leader-member exchange. Journal of Applied Psychology, 87, 590-598. 